\title{
Soil quality indicators under management systems in a Quilombola community in the
}

\section{Brazilian Cerrado}

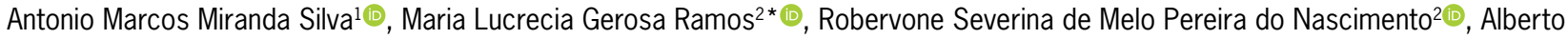

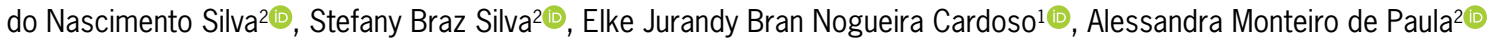

IUniversidade de São Paulo/ESALQ - Depto. de Ciência do Solo, Av. Pádua Dias, 11 - 13418-900 - Piracicaba, SP Brasil.

2Universidade de Brasília/FAV, Ala Central do Instituto Central de Ciências - 70297-400 - Brasília, DF - Brasil.

*Corresponding author <lucreciaunb@gmail.com>

Edited by: Paulo Cesar Sentelhas

Received January 15, 2018

Accepted July 02, 2018
ABSTRACT: Soil management systems exert different effects on soil attributes, especially on the organic matter content, and, consequently, the soil aggregation. The aim of this study was to evaluate the impact of different land uses practiced by quilombola family farmers on water stable aggregates, glomalin and organic carbon in soil aggregates. Soil samples were collected at depths of $0-10$ and $10-20 \mathrm{~cm}$ from areas cultivated under the following management systems: 1) conventional corn plantation (MA), 2) cultivation of citrus trees intercropped with annual crops (AC) (a conservationist approach), 3) pasture of Brachiaria (Urochloa spp.) (PA), and, as reference, an area of the Cerrado (CR) free of any anthropogenic interference. The studied areas were evaluated in a completely randomized design, with five replications, in a subplot scheme. The plots were the management systems and the subplots the depths. Soil macro-aggregates were predominant at both depths and the aggregate stability indices were higher than $90 \%$ for all management systems. Total organic carbon in the two aggregate classes (micro and macroaggregates) correlated with the MWD (mean weight-diameter), but not with the easily extractable glomalin (EEG) related soil protein. Soil micro and macro-aggregates, EEG and MWD discriminated management systems and are important soil quality indicators. The carbon content in both micro-aggregates (C-MIC) and macro-aggregates (C-MAC) of the intercropped system (AC) was higher than in the CR. The soil attributes that best separated the areas were C-MIC, MWD and EEG in macro-aggregates for the depth of $0-10 \mathrm{~cm}$, and $E E G$ in micro-aggregates, together with MWD and C-MAC for the depth of $10-20 \mathrm{~cm}$.

Keywords: Rhodic Hapludox, water-stable aggregates, soil protein, quilombo

\section{Introduction}

In Brazil, the Cerrado is the second largest biome, after the Amazon, and much of it is located in the Central Plateau, consisting of flat areas, shrub vegetation and marked seasonality with abundant summer rains (Dec to Mar) and dry winters (May to Sept) (Buol, 2009). In the Brazilian Cerrado, there are communities formed by ethnic-racial groups with a presumption of African ancestry, called quilombolas (INCRA, 2017). These communities practice family farming, based on giving due esteem to the local and traditional knowledge of farmers in order not to interfere with natural resources and processes. The agricultural management practices applied in quilombola communities do not have any technical assistance, which, in time, leads to a decrease in productivity. Thus, it is necessary to evaluate soil quality (SQ) indicators of the areas used by these communities in order to contribute to greater productivity (Nascimento et al., 2017).

SQ is the ability of soil to sustain productivity and biological diversity as well as promoting the health of the organisms that inhabit the area (Doran and Safley, 1997), thus resulting in soil functionality and sustainability of the system consisting of soil, plants, and microorganisms (Cardoso et al., 2013). Soil aggregates and the porous soil system integrated into the soil structure are key components of SQ (Pires et al., 2017).
The formation and stability of aggregates results from the interaction between biotic and abiotic factors (Tisdall and Oades, 1982). Among the factors that affect the formation of aggregates and their stability, are the arbuscular mycorrhizal fungi (AMF) (Rillig et al., 2015) which, together with plant roots, form the symbiotic mycorrhizae. AMF synthesize in their hyphae a compound with a cementing function, consisting of a glycoprotein linked to nitrogen, called glomalin (EEG) (Wu et al., 2014). The other factors that affect SQ are soil organic matter (Kimura and Scotti, 2016), soil texture (Gonçalves et al., 2017), soil fauna (Jouquet et al., 2016), and plant and microorganism diversity (Gould et al., 2016), among others. Conventional management, with intense plowing and tilling, often lead to crop systems with low plant biomass diversity, resulting in changes in the soil physical, chemical and biological attributes (Ahmed et al., 2017).

Thus, the aim of the present study was to evaluate the effect of land uses employed by quilombola family farmers on soil properties and finally on soil quality.

\section{Materials and Methods}

The study was carried out in a quilombola community (Quilombo Mesquita) belonging to the municipality of Cidade Ocidental in the eastern region of the state of Goiás, Brazil $\left(16^{\circ} 04^{\prime} 41^{\prime \prime} \mathrm{S}\right.$ and $47^{\circ} 52^{\prime} 05^{\prime \prime}$ 
W), at an altitude of $1014 \mathrm{~m}$. The climate of the region, according to Köppen's classification, is type Cwa high altitude tropical, with well-defined dry and rainy seasons. The mean annual temperature is $21^{\circ} \mathrm{C}$ and the mean annual rainfall 1,500 $\mathrm{mm}$ (Alvares et al., 2013).

The soil is a Rhodic Hapludox (Soil Survey Staff, 2010), and the physical and chemical soil properties have been described by Nascimento et al. (2017) (Table 1). Distinct historical management systems that were predominantly used by the quilombola community were selected (Table 2): 1) conventional corn planting (MA), 2) cultivation of citrus trees intercropped with annual crops (AC) (a conservationist approach), 3) Brachiaria (Urochloa spp.) pasture (PA). In addition to the cultivated areas, an area of the Cerrado (CR), free from any anthropogenic interference, was used as a reference.

We took soil samples along an imaginary diagonal line at depths of $0-10$ and $10-20 \mathrm{~cm}$ in Jan 2016. The localization of the studied areas and the soil sampling points can be found in Figure 1. We obtained five sub- samples at every $50 \mathrm{~m}$ to construct a composite sample. We collected samples in the row and between rows of the conventional corn cultivation system (MA) and in the shadow of treetops in the conservation system of citrus trees intercropped with annual crops (AC). The soil monoliths, collected to analyze the stability of the aggregates in water, were stored in plastic bags to maintain moisture and the stability of their structure. We fractioned all the soil making up the samples, according to points of weakness, so that the total sample volume would pass through an $8.0 \mathrm{~mm}$ sieve. Fragments of plants, cuttings and other residues that were retained on the sieve were excluded from the analysis. We used airdried samples for subsequent analyses.

Stability of the soil aggregates was determined by the vertical wet sieving method in a Yoder device (Yoder, 1936), which consists of separating the aggregates into size classes (Silva et al., 2016a). From the values of the aggregate masses, we calculated the following parameters: (1) the mean weight-diameter (MWD) and (2) the aggregate stability index (ASI).

Table 1 - Soil particle size distribution and chemical characteristics under the investigated management systems at 0-20 cm depth.

\begin{tabular}{|c|c|c|c|c|c|c|c|c|c|c|c|}
\hline \multirow{2}{*}{$\begin{array}{l}\text { Management } \\
\text { systems }^{1}\end{array}$} & \multicolumn{3}{|c|}{ Granulometry } & \multicolumn{8}{|c|}{ Chemical properties } \\
\hline & Sand & Silt & Clay & $\mathrm{pH}\left(\mathrm{H}_{2} \mathrm{O}\right)$ & $P$ & K & $\mathrm{m}$ & $\mathrm{Ca}^{2+}$ & $\mathrm{Mg}^{2+}$ & $\mathrm{Al}^{3+}$ & $\mathrm{H}+\mathrm{Al}$ \\
\hline & \multicolumn{6}{|c|}{$\mathrm{g} \mathrm{kg}^{-1}$} & $\%$ & \multicolumn{4}{|c|}{$\mathrm{cmol}_{\mathrm{c}} \mathrm{dm}^{-3}$} \\
\hline CR & 40 & 410 & 550 & 5.1 & 1.3 & 148 & 8.7 & 4.06 & 1.34 & 0.55 & 9.0 \\
\hline$A C$ & 40 & 410 & 550 & 5.8 & 3.7 & 308 & 0.6 & 6.34 & 1.95 & 0.06 & 5.7 \\
\hline PA & 120 & 280 & 600 & 4.7 & 2.1 & 118 & 41 & 0.34 & 0.28 & 0.64 & 5.9 \\
\hline MA & 40 & 410 & 550 & 5.9 & 8.4 & 353 & 0.4 & 4.57 & 1.28 & 0.03 & 4.1 \\
\hline
\end{tabular}

Table 2 - Description and history of the management systems.

\begin{tabular}{|c|c|c|}
\hline Management system & Acronym & History \\
\hline Native Cerrado & CR & $\begin{array}{l}\text { Remnant of the Cerradão, with forestry formation, used as a reference and without any exploration } \\
\text { or anthropic interference. Presence of species including Anadenanthera macrocarpa (Benth.) Brenan, } \\
\text { Lithraea molleoides (Vell.), Hymenaea courbaril L., Handroanthus avellanedae L. }\end{array}$ \\
\hline Brachiaria (Urochloa spp.) pasture & PA & $\begin{array}{l}\text { Area of approximately } 1 \text { ha }\left(10000 \mathrm{~m}^{2}\right) \text { occupied by pastures without soil preparation and fertility } \\
\text { management. For } 20 \text { years, there was rice/bean/corn/sugarcane rotation. In the last } 15 \text { years, there } \\
\text { was no management, but area left fallow, a period during which Urochloa decumbens (Stapf) Webster } \\
\text { and Urochloa brizantha (Stapf) Webster naturally invaded the location. There was no cattle grazing in } \\
\text { the area, and grasses were pulled manually while residues were left on the soil surface and area is not } \\
\text { used by farmers. }\end{array}$ \\
\hline Conventional corn planting & MA & $\begin{array}{l}\text { Area of approximately } 1 \text { ha }\left(10000 \mathrm{~m}^{2}\right) \text {, managed for } 30 \text { years, with planting of grains via conventional } \\
\text { practices of minimum soil preparation. For about } 20 \text { years, the rice/bean/corn rotation has been used, } \\
\text { without fertilization and liming. During the last } 10 \text { years, there has been harrowing every two years } \\
\text { and cultivation with corn only. Five years ago }(2011) \text {, liming was applied in the area, with one ton of } \\
\text { dolomitic limestone per hectare. The planting and fertilization of corn was manual, while fertilization is } \\
\text { performed near the plant row with the NPK formulation } 4-30-16\left(20 \mathrm{~g} \mathrm{~m}^{-1}\right) \text { and topdressing potassium } \\
\text { nitrate is used }\left(20 \mathrm{~g} \mathrm{~m}^{-1}\right) \text {. Weeds are present, but there is no straw on the soil. }\end{array}$ \\
\hline $\begin{array}{l}\text { Cultivation of citrus trees intercropped } \\
\text { with annual crops }\end{array}$ & $\mathrm{AC}$ & $\begin{array}{l}\text { Area of approximately } 0.25 \text { ha }\left(250 \mathrm{~m}^{2}\right) \text {. For } 21 \text { years, the area has been cultivated with Urochloa } \\
\text { decumbens (Stapf) Webster, fertilized with cattle manure, and the pasture maintained with continuous } \\
\text { cattle grazing. Pasture was removed and for four years the area has been cultivated with tangerine } \\
\text { (C. reticulata L.) }(4 \mathrm{~m} \times 4 \mathrm{~m}) \text { intercropped between rows, with the cultures corn/beans/cassava. In } \\
\text { the last two years, C. reticulata L. was intercropped only with cassava (Manihot esculenta L.). An initial } \\
\text { fertilization was performed with the formulation NPK } 4-30-16 \text { (400 g per plant) and with cattle manure } \\
\text { ( } 10 \mathrm{~L} \text { per plant). For two years, the area received coverage fertilization with formula NPK } 10-10-10 \\
\text { ( } 400 \text { g per plant). Weeds present in the area were pulled manually four times per year and the residues } \\
\text { left near the tree row. Mulching preserved in the area composed of fruit remains, leaves and weeds, } \\
\text { so that the soil is permanently covered. }\end{array}$ \\
\hline
\end{tabular}



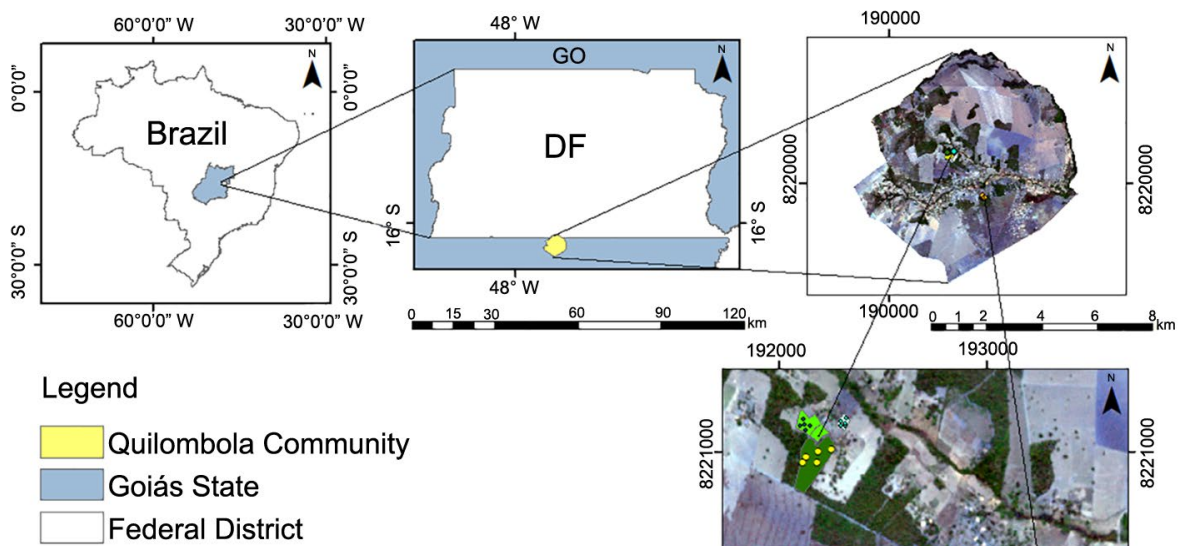

\begin{tabular}{|ll} 
Studied areas & Sample points \\
CR & $\circ$ CR \\
MA & - MA \\
PA & - PA \\
AC & $\circ$ AC
\end{tabular}

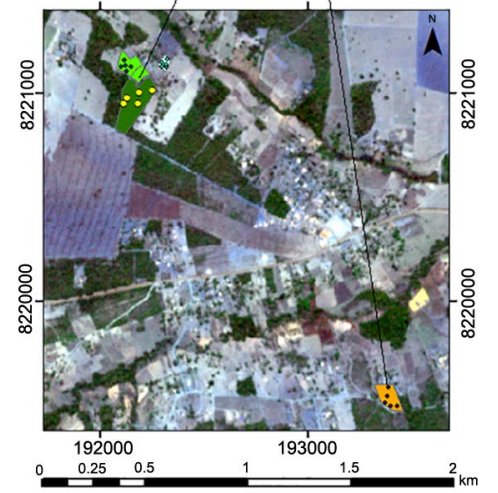

Figure 1 - Localization of studied areas and points of soil collection in Quilombo Mesquita ( $C R=$ Native Cerrado; $A C=$ Cultivation of citrus trees intercropped with annual crops; PA = Pasture of Brachiaria (Urochloa spp.); MA = Conventional corn planting).

$M W D=\sum_{i=l}^{n}(x i \cdot w i)$

$A S I=\left(\frac{\text { Dry sample weight }-w p 25-\text { sand }}{\text { Dry sample weight }- \text { sand }}\right)$

where: $w i=$ proportion $(\%)$ of each class $i$ in relation to the total aggregate weight; $x i=$ mean diameter of class $i$, obtained by [(upper mesh + lower mesh):2]; and wp25 $=$ weight of aggregates of the class $<250 \mu \mathrm{m}$.

The aggregates were subdivided into micro-aggregates $(<250 \mu \mathrm{m})$ and macro-aggregates (> $250 \mu \mathrm{m})$. The total organic carbon of each class of aggregates was quantified using oxidation by potassium dichromate according to the method of Walkley and Black (1934). Easily extractable glomalin (EEG) related soil protein of each aggregate class was extracted from the soil according to the methodology of Wright and Upadhyaya (1998) and quantified by the Bradford test (Bradford, 1976) using bovine serum albumin (BSA) as standard. We measured absorbance at $595 \mathrm{~nm}$ in a colorimeter (Carrizo et al., 2015).

The areas were analyzed in a completely randomized design, with five replications in subplots, where the plots were the management systems and the subplots the depths. The data were submitted to analysis of variance, after having met the normality criteria of the residues and homogeneity of variance, and subsequently multiple comparisons of the means were submitted to Tukey's test $(p \leq 0.05)$. We used canonical discriminant analysis (CDA) to separate the studied areas according to the analyzed variables. In addition, Pearson's correlation was plotted with the use of the program (R Core Team, 2017) and graphs were generated using MS Excel.

\section{Results and Discussion}

\section{Distribution of water-stable aggregates}

Soil macro-aggregates were predominant (around $90 \%$ ) at the depths evaluated in all systems (Figure 2). In areas of native Cerrado, we obtained similar results, with more than $90 \%$ of macro-aggregates stable in water (Bertolin et al., 2016). This may be related to the high clay content found in all management systems (Table 1), because there is a positive correlation of clay content with soil aggregation (Liu et al., 2012). Soils in tropical climates are highly influenced by electrostatic interactions between oxides and clay minerals of the $1: 1$ type in the aggregation process, forming microaggregates, which aggregate again by the action of biological agents, and form macro-aggregates (Costa Júnior et al., 2012).

There was no difference between the relative distribution of micro and macro-aggregates in the analyzed management systems $(p<0.05)$, suggesting that they do not interfere with the distribution of stable aggregates in water (Figure 2). Additionally, there were no changes in the percentage of micro and macroaggregates in the MA system, where harrowing practices were applied; and this may be related to the effect of lime application in 2011 and continuous crop rotation with rice (Oryza sativa L.), beans (Phaseolus vulgaris L.), 


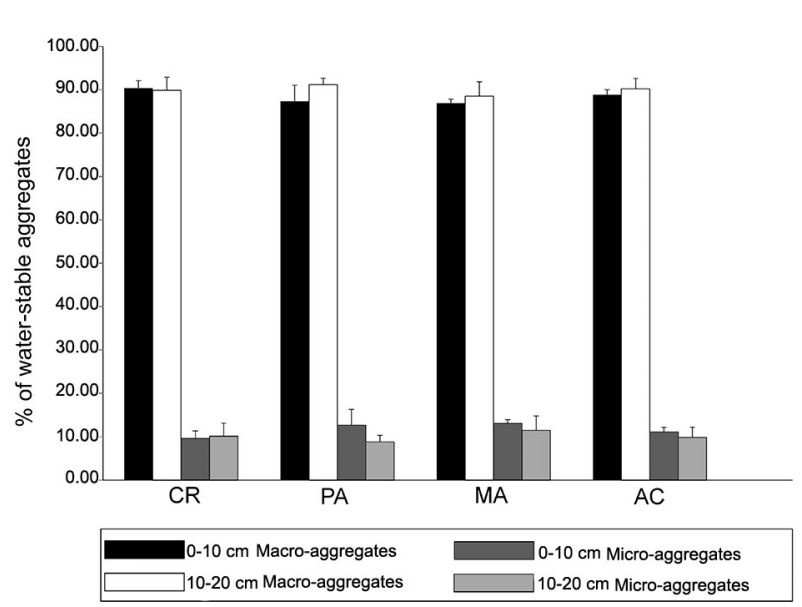

Figure 2 - Relative distribution of stable aggregates in water at depths of $0-10 \mathrm{~cm}$ and $10-20 \mathrm{~cm}$ submitted to the different management systems. $\mathrm{CR}=$ Native Cerrado; $\mathrm{PA}=$ Pasture of Brachiaria (Urochloa spp.); $\mathrm{MA}=$ Conventional corn planting; $\mathrm{AC}=$ Cultivation of citrus trees intercropped with annual crops.

and corn (Zea mays L.), for 20 years (Table 2). Silva et al. (2016b) reported that the application of limestone into a Rhodic Hapludox (the same as the one used in our study), increased the growth of root biomass and, consequently, the increase in aggregate stability.

All management systems presented distribution of water-stable aggregates similar to the reference area (CR) (Figure 2), indicating that, after several years of different soil management systems, there was no alteration of aggregate distribution. Soil aggregation seems to be favored by greater soil microbial diversity and active root growth, which allows an increase in interactions between microorganisms, soil and plants (Six et al., 2002; Tivet et al., 2013). Consequently, there may be a greater release of organic exudates that act as cementing agents between soil particles (Wang et al., 2017).

\section{Mean weight-diameter (MWD)}

The management system applied to the area with citrus trees intercropped with annual crops (AC) stood out from the other management systems evaluated for promoting significant variation $(p<0.05)$ in the MWD between the depths, with the highest values at 10-20 cm (Figure 3A). For the $0-10 \mathrm{~cm}$ depth, the AC, CR and PA systems presented the highest MWD values and did not differ between themselves ( $p<0.05)$. For the depth of $10-20 \mathrm{~cm}$, the AC system presented higher MWD and the MA was the management system with the lowest MWD.

For the last 10 years, the MA has been cultivated only with corn. The AC system was cultivated for 21 years with $U$. decumbens and fertilized with cattle manure. This same system was cultivated with $C$. reticulata intercropped with corn/beans/cassava for four years and in the last two years this area was intercropped only with cassava (Table 2). Soil management in AC promoted high- er MWD, probably due to a higher biodiversity above and below the soil surface, which has the potential to restore soil health (Cardoso et al., 2013).

The addition of plant biomass promotes the entry of easily decomposable carbon into the soil and favors an increase in the MWD. This effect is dependent on the quantity and quality of the organic material being supplied and may exhibit transient effects on the stability of aggregates (Lal, 2015). Moreover, the greater diversity of the planted species, especially grasses, due to their higher root biomass, increases the total organic carbon (TOC) and soil aggregate stability (Pérès et al., 2013). In the case of a Rhodic Hapludox, the organicmineral interaction between carbohydrates and the mineral surface of clay is one of the most important mechanisms in the formation of soil aggregates (Hanke and Dick, 2017).

We expected that the PA system would present higher MWD than the AC system, since it is known that areas under pasture have a greater tendency to present high levels of soil aggregation because of their fasciculate root system. They produce up to six $\mathrm{Mg}_{\mathrm{ha}} \mathrm{h}^{-1}$ of root biomass in the $0-30 \mathrm{~cm}$ layer (McNally et al., 2015), and these are constantly renewed. However, in the present study, the MWD in the PA was lower than in the AC in the 10-20 cm layer (Figure 3A), which could also be associated with lower content of silt and clay in PA in the $0-20 \mathrm{~cm}$ layer (Table 2). Soil textures with a higher silt and clay content are capable of binding $\mathrm{C}$ to the primary organic-mineral complex into silt-sized aggregates (Tisdall and Oades, 1982).

The MWD is dependent on plant root activity as well as on the quality and amount of metabolites which include organic acids and several other compounds secreted in the rhizosphere (Wang et al., 2017).

Such metabolites also select groups of microorganisms well adapted to the make up of the soil biodiversity thus assisting in the formation of the soil structure (Xiao et al., 2017).

We compared the general distribution of micro and macro-aggregates with the MWD, and found no influence on the distribution of stable macro and microaggregates in water (Figure 2). However, the MWD was lower in the MA system (Figure 3A) for both depths. This result may be related to the history of the area (Table 2) and the management system in which plowing and harrowing had been carried out every two years over the last 15 years.

\section{Aggregate stability index (ASI)}

There was no influence of ASI by soil use and management system (Figure 3B). Most of the aggregates were larger than $250 \mu \mathrm{m}$. However, their size distribution did not differ within management systems. The mineralogy of tropical soils is possibly the factor that results in increased stability of aggregates via the greater organic-mineral interaction (Madari et al., 2005; Hanke and Dick, 2017). A higher ASI was expected in the sys- 
tem with greater species diversity (AC), including the reference area $(\mathrm{CR})$, since both could promote a greater diversity of root exudates of different compositions, guaranteeing greater carbon source diversity in the soil system (Silva et al., 2016a). In addition to the biological diversity of natural systems that improves the stability of soil aggregates, another controversial aspect refers to spontaneous burning in the Cerrado that may or may not promote an increase in the stability of these aggregates (Thomaz, 2017; Hobley et al., 2017; Zhang et al., 2017).

Despite this, the ASI value found for the management systems lies within the range commonly found for tropical soils $(82 \pm 6 \%)$ (Thomaz, 2017). This may also be indicative of high resilience of the soils in these areas, which, according to history, have been cultivated for at least 20 years (Table 2).

\section{The total organic carbon in micro and macro- aggregates}

The total organic carbon content (TOC) in both the micro (C-MIC) and macro-aggregates (C-MAC) of the soil differed between the depths $(p<0.05)$ only in the reference area (CR) (Figures 3C and D). At the depth of 0-10 $\mathrm{cm}$, the C-MAC contents presented the following order: $\mathrm{AC}>\mathrm{CR}>\mathrm{MA}>\mathrm{PA}(p<0.05)$ (Figure 3D), while at that same depth the concentrations of C-MIC occurred in the following order: $\mathrm{AC}>\mathrm{CR}=\mathrm{MA}>\mathrm{PA}(p<0.05)$ (Figure $3 \mathrm{C}$ ). At the $10-20 \mathrm{~cm}$ depth, the contents of CMAC and C-MIC followed the same trend: AC > MA > $\mathrm{PA}=\mathrm{CR}(p<0.05)$ (Figures $3 \mathrm{C}$ and $\mathrm{D})$.

The AC management system showed higher TOC in the micro and macro-aggregates, possibly due to intercropping with tangerine (Citrus reticulata L.) and cassava (Manihot esculenta L.), and fertilization with cattle manure and accumulation of plant residues on the soil surface in the AC system. Lack of soil disturbance including the continuous root growth promoted by intercropping are all factors that result in the improvement of aggregation and the supply of carbon (C) to the soil.

Carbon retained within the micro-aggregates seems to be protected physically and chemically as well as a predominance of iron and aluminum oxide in tropical soil. Thus, the micro-aggregates can present high stability and behave like sand particles, and increase the $\mathrm{C}$ reserves in the soil (Braida et al., 2011; Silva et al., 2016a). In addition to protection in micro-aggregates,
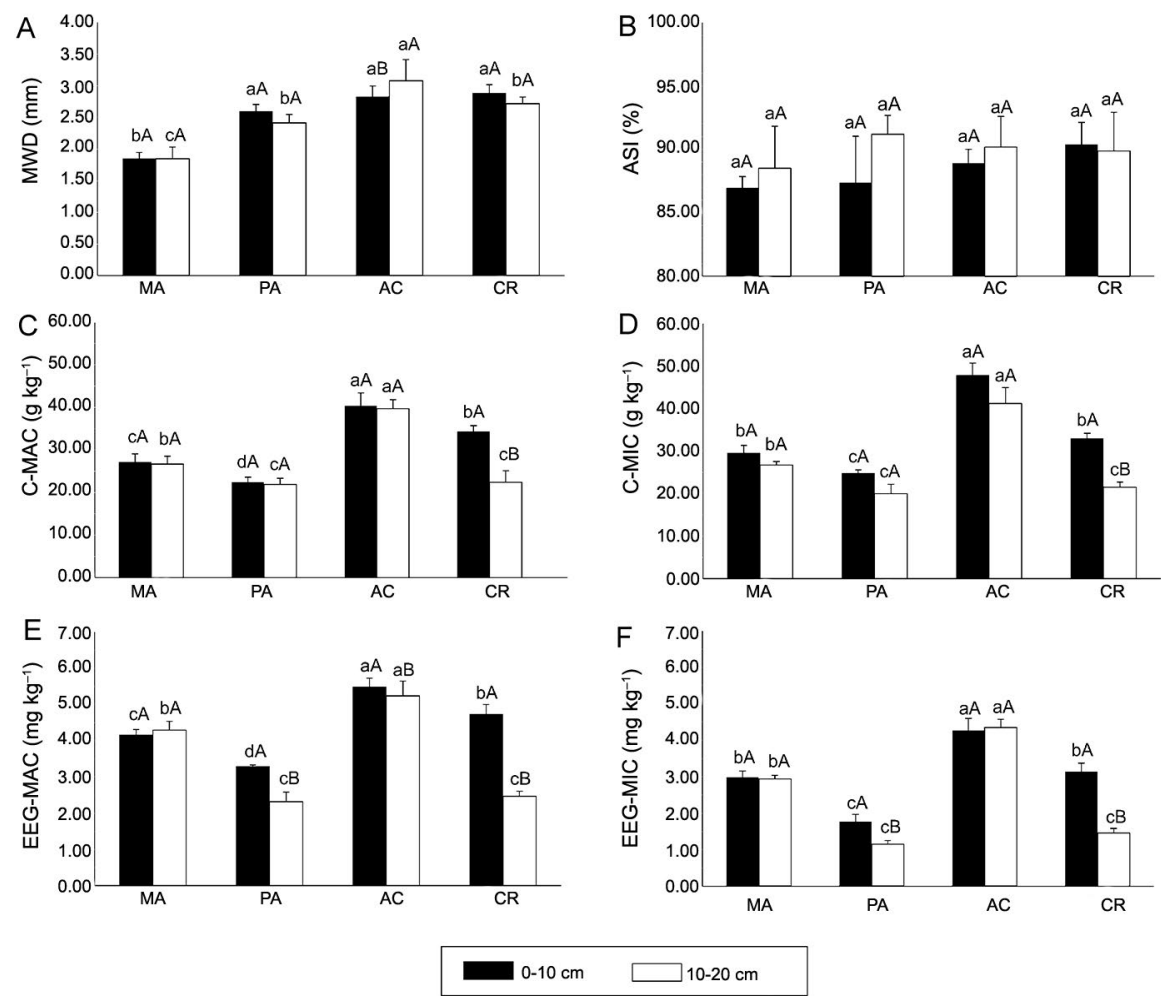

Figure 3 - A) Mean weight-diameter (MWD), B) aggregate stability index (ASI), C) total organic carbon in macro-aggregates (C-MAC), D) total organic carbon in micro-aggregates (C-MIC), E) easily extracted glomalin-related soil protein in macro-aggregates (EEG-MAC), F) and easily extracted glomalin-related soil protein in micro-aggregates (EEG-MIC) of soil submitted to different management systems. MA $=$ Conventional corn planting; $\mathrm{PA}=$ Pasture of Brachiaria (Urochloa spp.); $\mathrm{AC}=$ Cultivation of citrus trees intercropped with annual crops; $\mathrm{CR}=\mathrm{Native}$ Cerrado. Upper-case letters compare the depths within the same management system and lower-case letters compare a given depth among the different management systems by the Tukey's test at $5 \%(p<0.05)(n=5)$. 
$\mathrm{C}$ may have some protection in the macro-aggregates, according to the pore sizes (Kravchenko et al., 2015).

TOC contents in macro and micro-aggregates, obtained in our work, were greater than the contents obtained by Silva et al. (2016a) in a clay-textured Rhodic Hapludox in the Cerrado, with a mean value of $18.94 \mathrm{~g} \mathrm{C}$ $\mathrm{kg}^{-1}$ and $15.15 \mathrm{~g} \mathrm{C} \mathrm{kg}^{-1}$ for micro and macro-aggregates, respectively. The authors found no statistical differences in $\mathrm{C}$ content in soil cultivated with six cover crops in either micro or macro-aggregates.

It is known that the dynamics of $\mathrm{C}$ in soil is affected by different management practices (Nadal-Romero et al., 2016), but it is still unclear which class of soil aggregates is more responsible for the accumulation of $\mathrm{C}$ and which soils, depths and management factors are decisive in this process (Fernández et al., 2010). The management systems promoted increases in TOC as compared to levels in the Cerrado (CR) at the $10-20 \mathrm{~cm}$ depth (except for PA C-MIC). However, in the $0-10 \mathrm{~cm}$ layer, only AC increased TOC when compared with CR (both in micro and macro-aggregates).

\section{Easily extractable glomalin-related to soil protein in micro and macro-aggregates}

The EEG content exhibited a behavior similar to the carbon content in micro and macro-aggregates of the soil (Figure 3E and F), which reinforces the concept that EEG is an important source of soil organic carbon (Zhang et al., 2017). The highest EEG levels were found in the AC system, differing between the depths evaluated only in the EEG-MAC $(p<0.05)$, and the systems with the least EEG were the MA and PA (Figure $3 \mathrm{E})$. It has also been reported elsewhere in the literature that conservationist soil management with greater plant species diversity, associated with management practices that minimize degradation of the soil structure, presents a greater tendency to produce high EEG levels (Treseder and Turner, 2007; Vasconcellos et al., 2016).

The AC presented higher EEG than the CR in the micro and macro-aggregates at both depths. The AC system is characterized for being a dynamic system with regard to the input of organic material, as plant residues and manure (Table 2). In addition, the establishment of the AC occurred five years ago as an integrated system and presented the largest accumulation of TOC in different fractions of the soil organic matter (Nascimento et al., 2017).

In the reference area (CR), the contribution of biomass may or may not have a different rate from the intercropped system. In other management systems, which were not evaluated in the present study, without soil disturbance, the EEG content may remain constant over time (Souza et al., 2016), or vary due to the seasonality of precipitation (Buyer et al., 2011).

Macro-aggregates contained higher levels of EEG when compared to micro-aggregates, as had also been found by Vasconcellos et al. (2016), in areas of the Atlantic Forest Recovery in southeastern Brazil.
In macro-aggregates, action of the fungal mycelium network provides greater stability of aggregates in water (Zou et al., 2015) and this may be indicative of greater EEG synthesis (Kohler-Milleret et al., 2013).

\section{Relationship between the analyzed attributes}

The Wilks' Lambda multivariate test helps to discriminate between the significance of the studied attributes (Tables 3 and 4). The effect of the management system differed between the depths of $0-10 \mathrm{~cm}$ and 10$20 \mathrm{~cm}$ (Figures 4A and B). The canonical discriminant analysis (CDA) was selected to determine which attributes (or indicators) differentiate best the effect of the management systems. Contrary to principal component analysis (PCA), the CDA is a confirmatory evaluation whereas PCA is merely an exploratory analysis of the data, with no possibility of precisely determining the attributes that best distinguish the groups (Anderson and Willis, 2003).

For the depth of $0-10 \mathrm{~cm}$ (Table 3), the attributes that best discriminated the areas according to the Wilks' Lambda test were MWD ( $p<0.001)$, C-MIC ( $p<0.001)$, and EEG-MAC ( $p<0.05)$. For the depth of $10-20 \mathrm{~cm}$ (Table 4), the attributes that best discriminated the areas were MWD $(p<0.001)$, C-MAC $(p<0.05)$ and EEGMIC $(p<0.01)$. Thus, we observed that the common at-

Table 3 - Wilks' Lambda test between mean weight-diameter (MWD), aggregate stability index (ASI), total organic carbon in macroaggregates (C-MAC), total organic carbon in micro-aggregates (C-MIC), easily extractable glomalin-related soil protein in macroaggregates (EEG-MAC) and easily extractable glomalin-related soil protein in micro-aggregates (EEG-MIC) at the depth of $0-10 \mathrm{~cm}$.

\begin{tabular}{lcl}
\hline Soil attribute & Wilks' Lambda & \multicolumn{1}{c}{$p$-value } \\
\hline MWD & 0.001668 & $0.000132^{* * *}$ \\
ASI & 0.000429 & $0.299248^{\text {ns }}$ \\
C-MAC & 0.000484 & $0.159126^{\text {ns }}$ \\
C-MIC & 0.003820 & $0.000001^{* * *}$ \\
EEG-MAC & 0.000740 & $0.015014^{*}$ \\
EEG-MIC & 0.000296 & $0.827494^{\text {ns }}$ \\
\hline
\end{tabular}

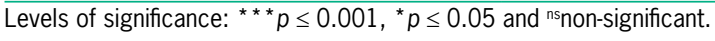

Table 4 - Wilks' Lambda test between mean weight-diameter (MWD), aggregate stability index (ASI), total organic carbon in macroaggregates (C-MAC), total organic carbon in micro-aggregates (C-MIC), easily extractable glomalin-related soil protein in macroaggregates (EEG-MAC) and easily extractable glomalin-related soil protein in micro-aggregates (EEG-MIC) at the depth of $10-20 \mathrm{~cm}$.

\begin{tabular}{lcc}
\hline Soil attribute & Wilks' Lambda & \multicolumn{1}{c}{$p$-value } \\
\hline MWD & 0.002901 & $0.000300^{* \star *}$ \\
ASI & 0.000806 & $0.407076^{\text {ns }}$ \\
C-MAC & 0.001319 & $0.028746^{*}$ \\
C-MIC & 0.000578 & $0.769238^{\text {ns }}$ \\
EEG-MAC & 0.000939 & $0.186470^{\text {ns }}$ \\
EEG-MIC & 0.002228 & $0.001408^{* *}$ \\
\hline Levels of significance: ${ }^{* * *} p \leq 0.001 ;{ }^{* *} p \leq 0.01 ;{ }^{*} p \leq 0.05 ;{ }^{\text {ns }}$ non-significant.
\end{tabular}




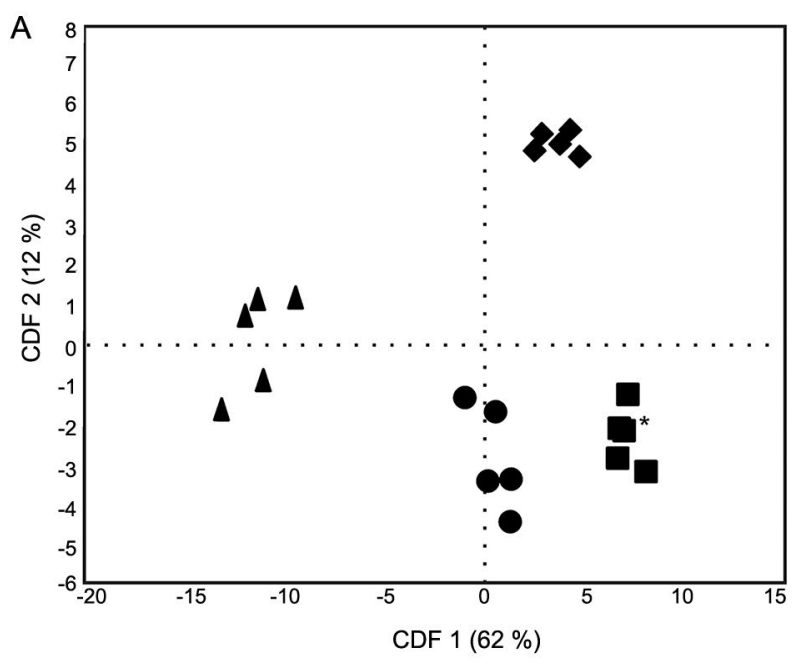

B

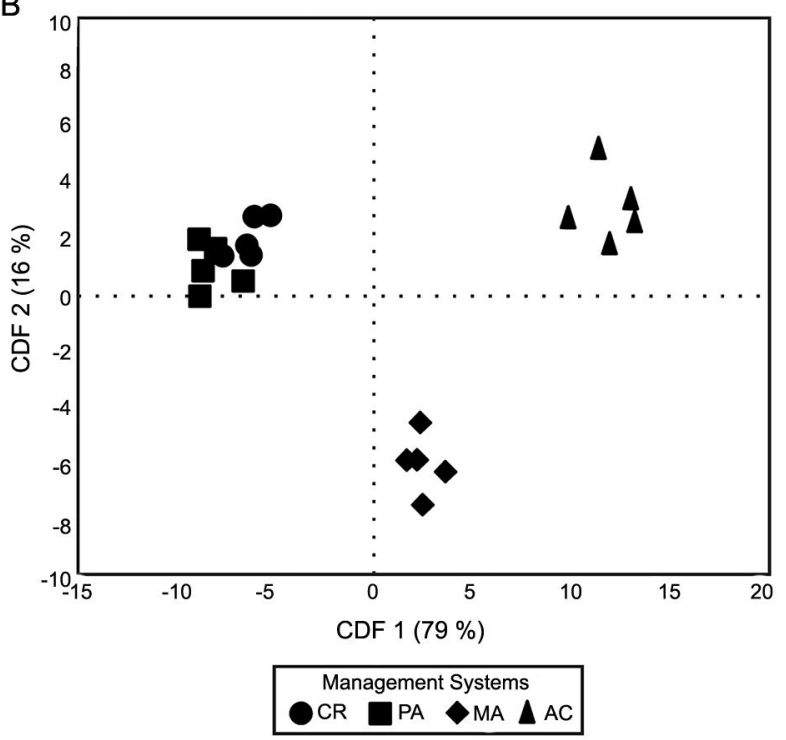

Figure 4 - Relationships between the first and second canonical discriminant functions (CDF1 and CDF2) on the centroids of standardized canonical coefficients (SCC) for the attributes mean weight-diameter (MWD), aggregate stability index (ASI), organic carbon in micro and macro-aggregates (C-MIC and C-MAC) and easily extractable glomalin in micro and macro-aggregates (EEGMIC and EEG-MAC) at depths of 0-10 cm (A) and 10-20 cm (B). $\mathrm{CR}=$ Native Cerrado; $\mathrm{PA}=$ Pasture of Brachiaria (Urochloa spp.); $\mathrm{MA}=$ Conventional corn planting and $\mathrm{AC}=$ Cultivation of citrus trees intercropped with annual crops; and $(n=5)$. ${ }^{*}$ There is an overlapping of repetitions of the PA samples at the depth of 0-10 $\mathrm{cm}(\mathrm{A})$.

tribute between the two depths that best discriminated the management systems was the mean weight-diameter (MWD). At the depth of $10-20 \mathrm{~cm}$ the reference area $(\mathrm{CR})$ and the PA system did not differ $(p \leq 0.05)$ in terms of the MWD, C-MIC, C-MAC, EEG-MAC and EEG-MIC (Figures $3 \mathrm{~A}$ to $\mathrm{F}$ ). The canonical discriminant function 1
Table 5 - Pearson's correlation among the attributes studied (MWD = mean weight-diameter, C-MIC = organic carbon in the microaggregates, C-MAC = organic carbon in the macro-aggregates, EEG-MIC = easily extractable glomalin-related soil protein in microaggregates and EEG-MAC = easily extractable glomalin-related soil protein in macro-aggregates).

\begin{tabular}{lllll}
\hline & MWD & C-MIC & C-MAC & EEG-MAC \\
\hline C-MIC & $0.42^{*}$ & & & \\
C-MAC & $0.48^{*}$ & $0.93^{* *}$ & & \\
EEG-MAC & $0.25^{\text {ns }}$ & $0.90^{* *}$ & $0.89^{* *}$ & \\
EEG-MIC & $0.26^{\text {ns }}$ & $0.92^{* *}$ & $0.91^{* *}$ & $0.96^{* *}$
\end{tabular}

Levels of significance: ${ }^{* *} p \leq 0.001 ;{ }^{*} p \leq 0.01$ and ${ }^{\text {ns non-significant. Data }}$ referring to the depths of $0-10 \mathrm{~cm}$ and $10-20 \mathrm{~cm}$.

$\left(\mathrm{CDF}_{1}\right)$ explained the greatest total variability of the attributes for both depths, between $0-10 \mathrm{~cm}(62 \%)$ and $10-$ $20 \mathrm{~cm}(79 \%)$, while the canonical discriminant function $2\left(\mathrm{CDF}_{2}\right)$ explained $12 \%$ and $16 \%$, respectively (Figures $4 \mathrm{~A}$ and $\mathrm{B})$.

EEG correlated with TOC, regardless of the class of aggregates (Table 5). It represents up to $52 \%$ and $25 \%$ of the total $\mathrm{C}$ content in organic and mineral soils, respectively (Schindler et al., 2007). Thus, TOC is directly proportional to the amount of EEG present in the soil (Zhang et al., 2017), and studies have proven this relationship to be true in soil cultivated with crops such as citrus (Poncirus trifoliata (L.) Raf.) (Wu et al., 2015) and corn (Zea mays L.) (Koide and Peoples, 2013).

The MWD did not correlate with the EEGMAC or the EEG-MIC (Table 4), indicating that EEG contributed more to carbon storage than MWD in the present study.

\section{Conclusions}

Soil macro and micro-aggregates, EEG and MWD discriminated management systems, and are important indicators of soil quality.

The carbon content in macro-aggregates (C-MAC) and micro-aggregates (C-MIC) of the intercropped system (AC) was higher than that of the CR.

The attributes that best separated the areas were C-MIC, MWD and EEG in macro-aggregates at the depth of $0-10 \mathrm{~cm}$, and EEG in micro-aggregates, MWD and C-MAC at the depth of $10-20 \mathrm{~cm}$.

\section{Authors' Contributions}

Conceptualization: Ramos, M.L.G.; Silva, A.M.M.; Nascimento, R.S.M.P.; Cardoso, E.J.B.N. Data acquisition: Silva, A.M.M.; Nascimento, R.S.M.P.; Silva, A.N.S.; Silva, S.B. Data analysis: Silva, A.M.M.; Paula, A.M.; Cardoso, E.J.B.N.; Ramos, M.L.G. Design of methodology: Silva, A.M.M.; Ramos, M.L.G.; Silva, A.N.S.; Silva, S.B. Writing and editing: Silva, A.M.M.; Ramos, M.L.G.; Cardoso, E.J.B.N.; Paula, A.M.; Silva, A.N.S. 


\section{References}

Ahmed, E.H.; Anjum, S.I.; Zhang, M. 2017. Effects of fertilization on phosphorus distribution in water-stable aggregates of soils with different properties. Toxicological \& Environmental Chemistry 2248: 32-47.

Alvares, C.A; Stape, J.L.; Sentelhas, P.C.; Gonçalves, J.L de M.; Sparovek, G. 2013. Köppen's climate classification map for Brazil. Meteorologische Zeitschrift 22: 711-728.

Anderson, M.J.; Willis, T.J. 2003. Canonical analysis of principal coordinates: a useful method of constrained ordination for ecology. Ecology 84: 511-525.

Bertolin, F.; Bono, J.A.M.; Macedo, M.C.M.; Araújo, A.R.; Pereira, F.A.R. 2016. Use and management of pasture in the Cerrado biome: impacts on aggregation of an oxisol. African Journal of Agricultural Research 11: 2139-2145.

Bradford, M.M. 1976. A rapid and sensitive method for the quantitation of microgram quantities of protein utilizing the principle of protein-dye binding. Analytical Biochemistry 72: 248-254.

Braida, J.A.; Bayer, C.; Albuquerque, J.A.; Reichert, J.M. 2011. Organic matter and its effect on soil physics = Matéria orgânica e seu efeito na física do solo. p. 222-227. In: Filho, O.K.; Mafra, A.L.; Gatiboni, L.C., eds. Topics in Soil Science = Tópicos em Ciência do Solo. Sociedade Brasileira de Ciência do Solo, Viçosa, MG, Brazil (in Portuguese).

Buol, S.W. 2009. Soils and agriculture in central-west and north Brazil. Scientia Agricola 66: 697-707.

Buyer, J.S.; Zuberer, D.A.; Nichols, K.A.; Franzluebbers, A.J. 2011. Soil microbial community function, structure, and glomalin in response to tall fescue endophyte infection. Plant and Soil 339: 401-412.

Cardoso, E.J.B.N.; Vasconcellos, R.L.F.; Bini, D.; Miyauchi, M.Y.H.; Santos, C.A.; Alves, P.R.L.; Paula, A.M.; Nakatani, A.S.; Pereira, J.M.; Nogueira, M.A. 2013. Soil health: looking for suitable indicators; what should be considered to assess the effects of use and management on soil health? Scientia Agricola 70: 274-289.

Carrizo, M.E.; Alesso, C.A.; Cosentino, D.; Imhoff, S. 2015. Aggregation agents and structural stability in soils with different texture and organic carbon contents. Scientia Agricola 72: 75-82.

Costa-Junior, C.; Píccolo, M.C.; Siqueira Neto, M.; Camargo, P.B.; Cerri, C.C.; Bernoux, M. 2012. Carbon in soil aggregates under native vegetation, pasture and agricultural systems in the Brazilian Savannah. Revista Brasileira de Ciência do Solo 36: 1311-1321 (in Portuguese, with abstract in English).

Doran, J.W.; Safley, M. 1997. Defining and assessing soil health and sustainable productivity. p. 1-28. In: Pankhurst, C.E.; Doube, B.M.; Gupta, V.V.S.R., eds. Biological indicators of soil health. CAB International, Wallingford, UK.

Fernández, R.; Quiroga, A.; Zorati, C.; Noellemeyer, E. 2010. Carbon contents and respiration rates of aggregate size fractions under no-till and conventional tillage. Soil and Tillage Research 109: 103-109.

Gonçalves, D.R.P.; Sá, J.C.M.; Mishra, U.; Cerri, C.E.P.; Ferreira, L.A.; Furlan, F.J.F. 2017. Soil type and texture impacts on soil organic carbon storage in a sub-tropical agro-ecosystem. Geoderma 286: 88-97.
Gould, I.J.; Quinton, J.N.; Weigelt, A.; De Deyn, G.B.; Bardgett, R.D. 2016. Plant diversity and root traits benefit physical properties key to soil function in grasslands. Ecology Letters 19: 1140-1149.

Hanke, D.; Dick, D.P. 2017. Aggregate stability in soil with humic and hystic horizons in a toposequence under araucaria forest. Revista Brasileira de Ciência do Solo 41: e0160369.

Hobley, E.U.; Le Gay Brereton, A.J.; Wilson, B. 2017. Forest burning affects quality and quantity of soil organic matter. Science of the Total Environment 575: 41-49.

Instituto Nacional de Colonização e Reforma Agrária [INCRA]. 2017. Quilombola Politics $=$ Política Quilombola. Available at: http://www.incra.gov.br/quilombola [Accessed Jan 10, 2017] (in Portuguese).

Jouquet, P.; Chintakunta, S.; Bottinelli, N.; Subramanian, S.; Caner, L. 2016. The influence of fungus-growing termites on soil macro and micro-aggregates stability varies with soil type. Applied Soil Ecology 101: 117-123.

Kimura, A.C.; Scotti, M.R. 2016. Soil aggregation and arbuscular mycorrhizal fungal indicators of slope rehabilitation in the São Francisco River basin (Brazil). Soil and Water Research 11: 114-123.

Kohler-Milleret, R.; Le Bayon, R.C.; Chenu, C.; Gobat, J.M.; Boivin, P. 2013. Impact of two root systems, earthworms and mycorrhizae on the physical properties of an unstable silt loam Luvisol and plant production. Plant and Soil 370: 251-265.

Koide, R.T.; Peoples, M.S. 2013. Behavior of Bradford-reactive substances is consistent with predictions for glomalin. Applied Soil Ecology 63: 8-14.

Kravchenko, A.N.; Negassa, W.C.; Guber, A.K.; Rivers, M.L. 2015. Protection of soil carbon within macro-aggregates depends on intra-aggregate pore characteristics. Scientific Reports 5: 16261.

Lal, R. 2015. Soil carbon sequestration and aggregation by cover cropping. Journal of Soil and Water Conservation 70: 329-339.

Liu, X.H.; Han, F.P.; Zhang, X.C. 2012. Effect of biochar on soil aggregates in the Loess Plateau: results from incubation experiments. International Journal of Agriculture and Biology 14: 975-979.

Madari, B.E.; Machado, P.L.O.A.; Torres, E.; Andrade, A.G.; Valencia, L.I.O. 2005. No tillage and crop rotation effects on soil aggregation and organic carbon in a Rhodic Ferralsol from southern Brazil. Soil and Tillage Research 80: 185-200.

McNally, S.R.; Laughlin, D.C.; Rutledge, S.; Dodd, M.B.; Six, J.; Schipper, L.A. 2015. Root carbon inputs under moderately diverse sward and conventional ryegrass-clover pasture: implications for soil carbon sequestration. Plant and Soil 392: 289-299.

Nadal-Romero, E.; Cammeraat, E.; Pérez-Cardiel, E.; Lasanta, T. 2016. How do soil organic carbon stocks change after cropland abandonment in Mediterranean humid mountain areas? Science of the Total Environment 566-567: 741-752.

Nascimento, R.S.M.P.; Ramos, M.L.G.; Figueiredo, C.C.; Silva, A.M.M.; Silva, S.B.; Batistella, G. 2017. Soil organic matter pools under management systems in Quilombola territory in Brazilian Cerrado. Revista Brasileira de Engenharia Agrícola e Ambiental 21: 254-260. 
Pérès, G.; Cluzeau, D.; Menasseri, S.; Soussana, J.F.; Bessler, H.; Engels, C.; Habekost, M.; Gleixner, G.; Weigelt, A.; Weisser, W.W.; Scheu, S.; Eisenhauer, N. 2013. Mechanisms linking plant community properties to soil aggregate stability in an experimental grassland plant diversity gradient. Plant and Soil 373: 285-299.

Pires, L.F.; Borges, J.A.R.; Rosa, J.A.; Cooper, M.; Heck, R.J.; Passoni, S.; Roque, W.L. 2017. Soil structure changes induced by tillage systems. Soil and Tillage Research 165: 66-79.

Rillig, M.C.; Aguilar-Trigueros, C.A.; Bergmann, J.; Verbruggen, E.; Veresoglou, S.D.; Lehmann, A. 2015. Plant root and mycorrhizal fungal traits for understanding soil aggregation. New Phytologist 205: 1385-1388.

Schindler, F.V.; Mercer, E.J.; Rice, J.A. 2007. Chemical characteristics of glomalin-related soil protein (GRSP) extracted from soils of varying organic matter content. Soil Biology and Biochemistry 39: 320-329.

Silva, A.N.; Figueiredo, C.C.; Carvalho, A.M.; Soares, D.S.; Santos, D.C.R.; Silva, V.G. 2016a. Effects of cover crops on the physical protection of organic matter and soil aggregation. Australian Journal of Crop Science 10: 1623-1629.

Silva, F.R.; Albuquerque, J.A.; Costa, A.; Fontoura, S.M.V.; Bayer, C.; Warmling, M.I. 2016b. Physical properties of a Hapludox after three decades under different soil management systems. Revista Brasileira de Ciência do Solo 40: e0140331.

Six, J.; Feller, C.; Denef, K.; Ogle, S.M.; Moraes, J.C.; Albrecht, A. 2002. Soil organic matter, biota and aggregation in temperate and tropical soils: effects of no-tillage. Agronomie 22: 755-775.

Soil Survey Staff. 2010. Keys to Soil Taxonomy. 11ed. USDANRCS, Washington, DC, USA.

Souza, E.D.; Carneiro, M.A.C.; Paulino, H.B.; Ribeiro, D.O.; Bayer, C.; Rotta, L.A. 2016. Organic matter and soil aggregation after the conversion of "murundu fields" into a no-tillage system. Pesquisa Agropecuária Brasileira 51: 1194-1202 (in Portuguese, with abstract in English).

Thomaz, E.L. 2017. High fire temperature changes soil aggregate stability in slash-and-burn agricultural systems. Scientia Agricola 74: 157-162.

Tisdall, J.M.; Oades, J.M. 1982. Organic matter and water stable aggregates in soils. Journal of Soil Science 33: 141-163.

Tivet, F.; Sá, J.C.M.; Lal, R.; Borszowskei, P.R.; Briedis, C.; Santos, J.B.; Sá, M.F.M.; Hartman, D.C.; Eurich, G.; Farias, A.; Bouzinac, S.; Séguy, L. 2013. Soil organic carbon fraction losses upon continuous plow-based tillage and its restoration by diverse biomass-C inputs under no-till in sub-tropical and tropical regions of Brazil. Geoderma 209-210: 214-225.
Treseder, K.K.; Turner, K.M. 2007. Glomalin in ecosystems. Soil Science Society of America Journal 71: 1257.

Vasconcellos, R.L.F.; Bonfim, J.A.; Baretta, D.; Cardoso, E.J.B.N. 2016. Arbuscular mycorrhizal fungi and glomalin-related soil protein as potential indicators of soil quality in a recuperation gradient of the Atlantic Forest in Brazil. Land Degradation and Development 27: 325-334.

Walkley, A.; Black, I.A. 1934. An examination of the Degtjareff method for determining soil organic matter, and a proposed modification of the chromic acid titration method. Soil Science 37: 29-38.

Wang, Z.H.; Fang, H.; Chen, M. 2017. Effects of root exudates of woody species on the soil anti-erodibility in the rhizosphere in a karst region, China. Peer J 5: e3029.

Wright, S.F.; Upadhyaya, A. 1998. A survey of soils for aggregate stability and glomalin, a glycoprotein produced by hyphae of arbuscular mycorrhizal fungi. Plant and Soil 198: 97-107.

Wu, Q.S.; Cao, M.Q.; Zou, Y.N.; He, X.H. 2014. Direct and indirect effects of glomalin, mycorrhizal hyphae, and roots on aggregate stability in rhizosphere of trifoliate orange. Scientific Reports 4: 5823.

Wu, Q.S.; Li, Y.; Zou, Y.N.; He, X.H. 2015. Arbuscular mycorrhiza mediates glomalin-related soil protein production and soil enzyme activities in the rhizosphere of trifoliate orange grown under different $P$ levels. Mycorrhiza 25: 121-130.

Xiao, S.; Zhang, W.; Ye, Y.; Zhao, J.; Wang, K. 2017. Soil aggregate mediates the impacts of land uses on organic carbon, total nitrogen, and microbial activity in a Karst ecosystem. Scientific Reports 7: 41402.

Yoder, R.E. 1936. A direct method of aggregate analysis of soil and a study of the physical nature of erosion losses. Agronomy Journal 28: 337-351.

Zhang, M.; Cheng, G.; Feng, H.; Sun, B.; Zhao, Y.; Chen, H.; Chen, J.; Dyck, M.; Wang, X.; Zhang, J.; Zhang, A. 2017. Effects of straw and biochar amendments on aggregate stability, soil organic carbon, and enzyme activities in the Loess Plateau, China. Environmental Science and Pollution Research 24: 10108-10120.

Zou, Y.N.; Srivastava, A.K.; Ni, Q.D.; Wu, Q.S. 2015. Disruption of mycorrhizal extraradical mycelium and changes in leaf water status and soil aggregate stability in rootbox-grown trifoliate orange. Frontiers in Microbiology 6: 1-9. 